\author{
Anna Januchta-Szostak \\ Agata Karaśkiewicz \\ Poznań University of Technology \\ Faculty of Architecture \\ anna.januchta-szostak@put.poznan.pl
}

\title{
RECREATIONAL DEVELOPMENT IN THE SETTLEMENTS OF THE WARTA VALLEY IN WIELKOPOLSKA
}

\begin{abstract}
Riverside areas have substantial recreational and tourist assets, but their potential in the settlements of Wielkopolska is underused due to difficult access to the river and the poor development of the embankments. The aim of the research is to analyse the functional-spatial structure and the development of River Warta areas in the settlements of Wielkopolska with respect to their usefulness in recreation. Particular attention is paid to accessibility and the location of recreational infrastructure in the Warta Valley. Out of the eleven Wielkopolska settlements which were included, only in four - Konin, Śrem, Poznań and Sieraków - had sections of embankment boulevards been built. In the riverside areas there are few recreational facilities used in connection with the close proximity of the river. However, a great tourist asset of the Warta Valley is the Great Waterway Loop of Wielkopolska, which operates successfully due to the growing number of harbours and marinas in all the settlements included in the study.
\end{abstract}

Keywords: River Warta, riverside boulevards, promenades, public space, recreational infrastructure.

\section{INTRODUCTION}

Rivers and river valleys are an important element of the functional-spatial structure of cities and regions (e.g. TOŁWIŃSKI 1948, PANCEWICZ 2004, BERNAT 2007, MUSZYŃSKA-JELESZYŃSKA 2013). Their recreational potential, understood as the "landscape's ability to create conditions enabling people to satisfy their need to rest and restore their biological, mental and physical strength" (RICHLING 1992), is the basis of recreational development.

The recreational potential of the urban sections of river valleys depends not only on the quality of the natural environment and assets of the cultural landscape, but also on the accessibility of embankments, continuity of riverside and water trails, as well as the quantitative and qualitative state of the recreational infrastructure.

The 'Territorial Recreation System' (PRIEOBRAŻENSKIJ \& WIEDIENIN 1971) encompasses natural and human assets, technical infrastructure, those working within the tourism sector and tourism management, as well as those participating in recreation (PIETRZAK 2013). In the study presented here, the authors focus above all on the functional-spatial aspects of the Warta Valley, particularly on the functions of the existing buildings, area de- velopment, as well as the elements of technical infrastructure which determine the recreational and tourism functions of the area.

\section{RESEARCH AIMS, SCOPE AND METHODS}

Urban riverside areas (URA's) and the factors determining their development are the research object ${ }^{1}$. They include the satisfaction of the recreational needs of inhabitants as well as tourism development based on the landscape potential and the presence of recreational infrastructure in the river valleys. Certain parts of the research may be useful to update knowledge on the recreational development of the Warta Valley in Wielkopolska.

The aim is to analyse the functional-spatial structure and the development of the Warta riverside areas in the settlements of Wielkopolska, including their usefulness for recreation. The study concerns eleven settlements on the River Warta along the Great Waterway Loop of Wielkopolska within the boundaries of Wielkopolskie 
Province: Konin, Pyzdry, Śrem, Puszczykowo, Luboń, Poznań, Oborniki, Obrzycko, Wronki, Sieraków and Międzychód.

The scope of the research included the following:

- analysis of the riverside areas intended to have recreational functions, their development level, as well as restrictions resulting from flood hazards and flood risk;

- analysis of the accessibility and continuity in development of embankments, with a particular consideration of the location of riverside boulevards and promenades;

- analysis of the recreational infrastructure, especially that which is related to water tourism, on the basis of the location and facilities available at marinas and river harbours.

The researchers used the method of overlay analysis², as well as cartographic and statistical techniques, making use of planning documents and flood hazard and risk maps. They also compared the results of field questionnaires and analysed internet databases, includeing satellite photographs, orthophoto maps and commonly accessible PIB portals ${ }^{3}$, which enabled them to conduct a multi-criteria analysis, based on interdisciplinary coordination.

\section{RECREATIONAL DEVELOPMENT OF RIVERSIDE URBAN AREAS}

River valleys in towns combine natural and cultural structures. The meeting point of these environments forms an area of potentially valuable recreational assets, but also a place of conflict and risks (e.g. flood hazards or threats to the natural environment). Appropriate recreational development makes it possible to improve accessibility as well as the functional and visual attarctiveness of these areas and increase the protection of valuable ecosystems preserving natural 'absorbency' and 'passability' of migration corridors. However, the risk of flooding and the hydrological conditions are reasons why land development in riverside areas is limited.

The perception-behavioural potential (PRZEWOŹNIAK 1991), showing in the influence of landscape on the human senses, behaviour and activities, is of key importance as regards evaluation of the usefulness of river valleys for recreation ${ }^{4}$ and tourism. The broad foreground of the river opens a panorama, which is significant from the point of view of tourism (viewing a settlement from waterways and riverside tourist trails) and the recreational needs of the inhabitants (the pleasure of a distant view). However, it is not always true that city waterfronts are visually attractive; degraded buildings and open space, views blocked by embankments, as well as the poor quality of the recreational and hydrotechnical infrastructure are often found there.

Elements which are very important for the evaluation of the functional-spatial structure and the development of URA's, with respect to their tourist-recreational usefulness, include surface, point and linear (KOWALCZYK \& DEREK 2010), i.e. surfaces - URA's (their functions and the landscape assets of waterfronts); points (nodal public spaces and the distribution of tourismrecreational facilities and infrastructure); as well as linear connections (the system of roads, tourist trails and paths securing the continuity of the riverside, communication with the city and the accessibility of embankments). Particularly significant are facilities connected with water and water-side activity such as beaches, river harbours, marinas, rowing and yachting clubs ${ }^{5}$, but the range of recreation options is also enlarged by sports and cultural facilities which do not directly involve access to water, such as football grounds and sports halls, shooting ranges, stadiums, entertainment centres, amphitheatres, museums, etc.

\section{RESEARCH ON THE DEVELOPMENT OF URA'S}

In the study of the functional-spatial structure of the Warta riverside areas in eleven settlements of Wielkopolska, the authors identified surface, linear and point elements, and analysed their usefulness for recreational and tourist functions. The analyses were conducted with regard to the following: 1) riverside areas intended to have recreational functions; 2) accessibility and continuity in the development of embankments, particularly the presence of boulevards and riverside promenades as linear elements; 3) point elements of recreational infrastructure, particularly marinas and harbours, related to water recreation and tourism.

\subsection{RIVERSIDE AREAS INTENDED TO HAVE RECREATIONAL FUNCTIONS (SURFACE ELEMENTS)}

The functional analysis of the riverside areas was conducted using the overlay analysis method ${ }^{6}$, on the basis of local planning and strategic documents including $\mathrm{SUiKZP}^{7}$, in order to define the percentage of sports and recreation grounds, as well as managed open areas in the urban waterside zone ${ }^{8}$. The zone consisted of waterside areas (including areas above the flood plain) which were about $100 \mathrm{~m}$ wide or delineated by the nearest street parallel to the embankment. 
The results of the study (Fig. 1) show that the highest percentage of areas intended to have sport, recreation and managed open functions ${ }^{9}$ can be found in Sieraków at 27\%. In the other towns, this percentage ranges between 5.3\% (Puszczykowo) and 12.0\% (Wronki). In Pyzdry, Oborniki and Obrzycko, SUiKZP records do not define URA development as areas of sport, recreation or managed open areas. The situation in powiat towns is extreme. In Konin, areas intended to have a recreational function make up less than $2 \%$, while in Poznań it is about $17 \%$.

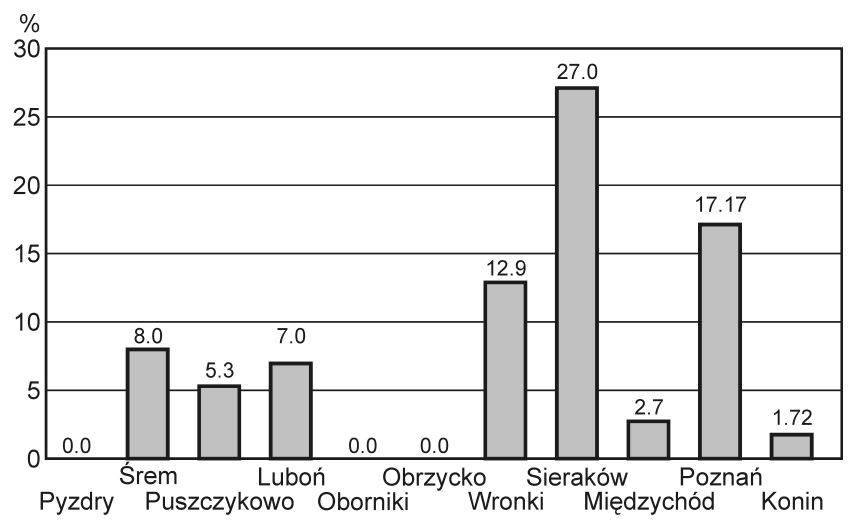

Fig. 1. The percentage of areas intended to have sport, recreation and managed open areas along the URA belt, based on the current SUiKZP

Source: A. Karaśkiewicz (Florkowska)

The settlements of Wielkopolska, situated on the Warta, were also analysed for their recreational functions in areas threatened with flooding. Based on flood hazard and flood risk maps ${ }^{10}$, the authors defined the percentage of recreational areas particularly threatened with flooding ${ }^{11}$ and those at the risk of being flooded if embankments are breached.

Out of all the settlements, in the stretches of land particularly threatened with flooding, recreational areas can be found only in Wronki, where they cover about $11 \%$, and in Poznań (not more than $0.5 \%$ ).

In six towns (Koło, Pyzdry, Śrem, Międzychód, Konin and Poznań), there is an anti-flood infrastructure in the form of embankments, and in three settlements (Śrem, Konin and Poznań), the researchers found areas intended for recreation which were cut off by embankments (but still at the risk of flooding if they were damaged), ranging from $5 \%$ in Konin to over $50 \%$ in Poznań. In Śrem, recreational functions occur in $20 \%$ of the areas at risk of flooding if embankments are breached (Fig. 2).

The high percentage of areas intended for recreation (27\%) recorded in the small town of Sieraków, prompts further research in order to define the factors stimulat- ing the development of the recreational functions in riverside areas. Perhaps, in the case of Sieraków, this result is an effect of implementing a local development strategy, focused on using the tourism potential of the town. The different percentages of areas intended to have recreational functions in the URA zone in individual settlements of Wielkopolska may result from local spatial conditions, the range and level of flood risk, or from socio-economic factors. It is interesting that the percentage of recreational functions in the URA district of Konin $(1.72 \%)$ is low despite the building of a long boulevard section in this town.

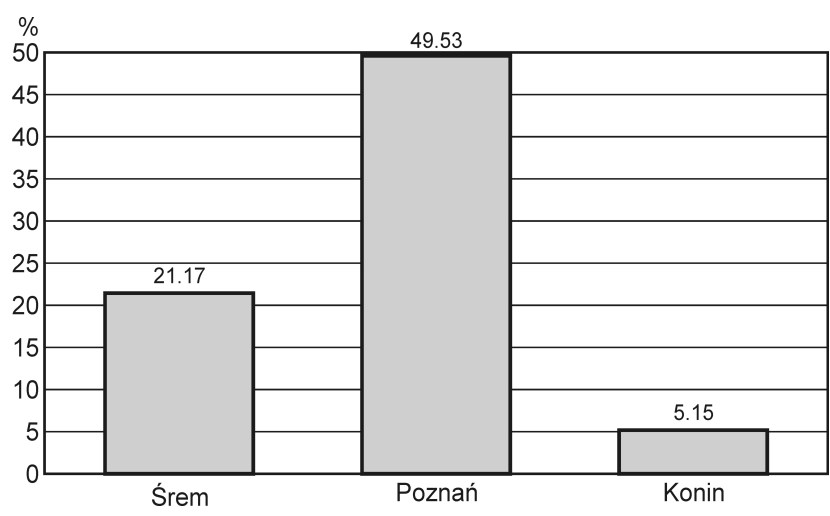

Fig. 2. The percentage of recreational areas at risk of flooding if embankments are breached Source: A. Karaśkiewicz (Florkowska)

More extensive research on the URA functional structure (JANUCHTA-SZOSTAK \& FLORKOWSKA 2016; FLORKOWSKA 2017) confirmed the highest percentage of grassland and arable land, which is an appropriate form of land development with respect to the eco-hydrological conditions. One might be surprised, however, by the small percentage of recreational functions, considering the common feeling that there are too few recreational areas in these settlements.

Intensive development in areas threatened with flooding increases its risk which is one of the most important reasons for limiting investment (apart from restrictions following from the 'Water Law') as well as those areas at risk if the embankments are broken. However, if an area is intended to have recreational functions, it does not necessarily mean erecting buildings.

The evaluation of the recreational usefulness of URAs requires an analysis of the aesthetic assets of the waterfront landscapes, including a study of the effect of embankments on the perception of the town and the river. It is also necessary to conduct an analysis of recreational capacity (including 'natural capacity'). Such studies are scheduled for the next stage of research. 


\subsection{ANALYSIS OF THE ACCESSIBILITY AND CONTINUITY IN THE DEVELOPMENT OF EMBANKMENTS: \\ RIVERSIDE BOULEVARDS AND PROMENADES (LINEAR ELEMENTS OF THE TOURIST- RECREATIONAL INFRASTRUCTURE)}

Linear elements of the transportation infrastructure make it possible to use areas situated along the river for recreational purposes (e.g. walking, jogging, cycling), as well as to create very attractive riverside tourist trails. Recreational activation of URAs greatly depends on the form and accessibility of embankments, 'passability' and the continuity of riverside trails. In order to be used for recreation in urbanized areas, river valleys must be easy to access, both from land and water (Fig. 3). The aim of the analysis is to confirm the presence of riverside boulevards and promenades in settlements on the Warta as well as verify access to the embankments from them. Accessibility from the river will be analysed in the next section which discusses the location of ports and harbours along the Warta waterway.

Research into the accessibility and development of the embankments was based on internet databases including satellite photographs, orthophoto maps and commonly available BIP portals. The results were verified and complemented, using observation and inventory methods during field questionnaires.

Research into the accessibility and development of the embankments was based on internet databases including satellite photographs, orthophoto maps and commonly available BIP portals. The results were verified and complemented, using observation and inventory methods during field questionnaires.

Accessibility was examined by analyzing horizontal and vertical transport connections. Horizontal connec- tions included streets and pedestrian walkways (hard and soft surfaces), tourist trails and walking paths, and cycling trails. Vertical connections were inventoried as steps, ramps and slipways which enabled people to cope with differences in height between buildings and the river ${ }^{12}$. The authors also paid attention to ramps adjusted to the needs of the disabled, as well as defining the length of the boulevards and the proportion of their length to that of the river within the administrative boundaries.

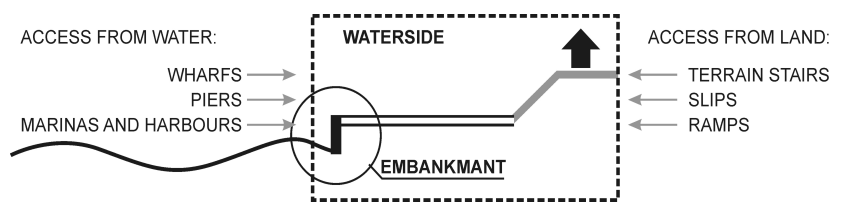

Fig. 3. Accessibility of the waterside and embankment zones Source: A. Januchta-Szostak \& A. Karaśkiewicz (Florkowska)

Out of all the settlements situated on the Warta in Wielkopolska, 30\% have riverside pathways in the form of boulevards and promenades (Fig. 4): Konin, Śrem, Poznań and Sieraków.

In Śrem, the length of the promenade is about $2 \mathrm{~km}$, which is nearly $50 \%$ of the length of the river within the administrative boundaries of the town. Boulevards in Konin (Photo 1) are nearly $1 \mathrm{~km}$ long, which makes up $9 \%$ of the river's length within the city limits. The total length of the Wartostrada sections in Poznan (Photo 2) is $5 \mathrm{~km}$, which is $23 \%$ of the length of the river in the city, and the promenade in Sieraków (Photo 3), about $200 \mathrm{~m}$ long, has a very fragmentary character and does not exceed 3\% of the length of the river. In other towns, the role of horizontal traffic routes is played by sections of riverside streets (e.g. in Pyzdry, Koło, Puszczykowo

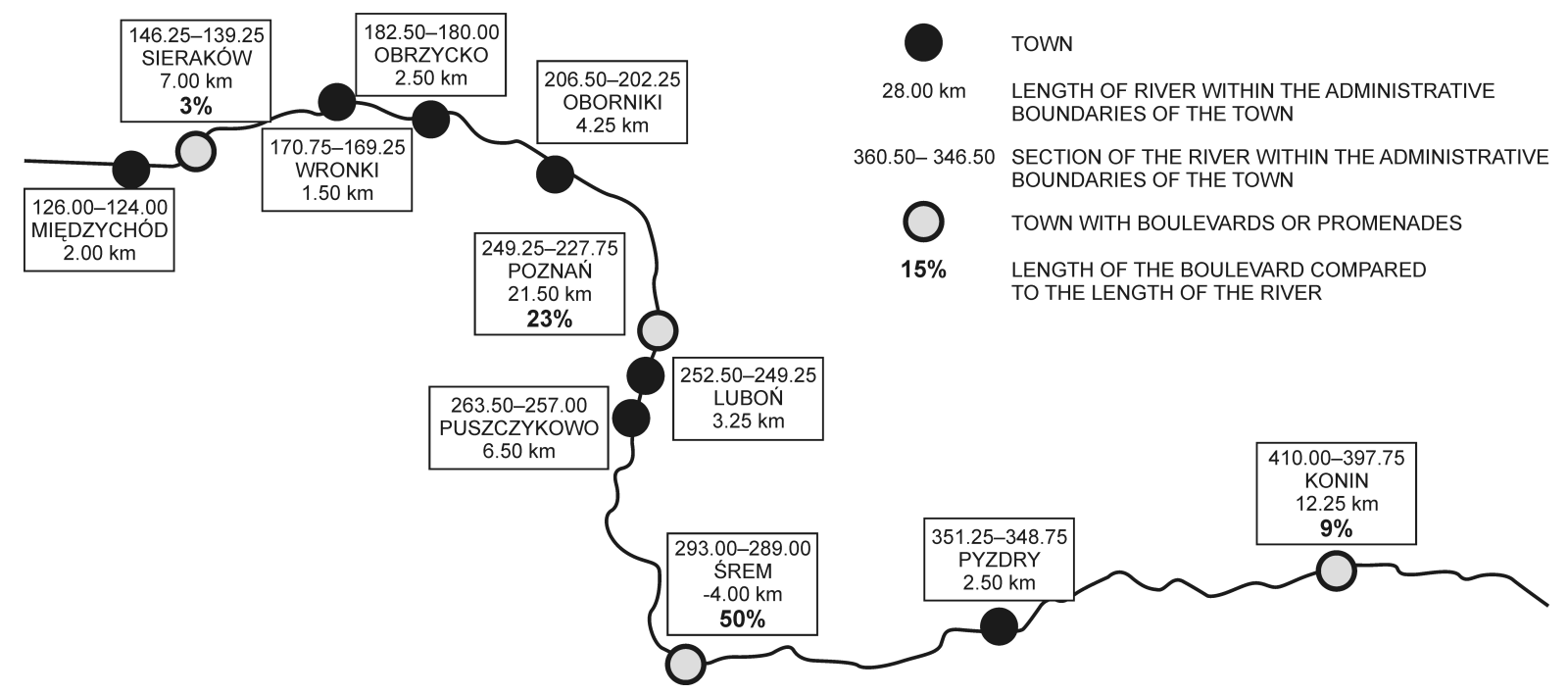

Fig. 4. Settlements on the Warta River in Wielkopolska with boulevards and promenades Source: A. Karaśkiewicz (Florkowska) 
and Międzychód) and dirt paths. Occasionally, informal riverside paths ${ }^{13}$ are difficult to access due to the lack of steps or slipways (e.g. in Oborniki). Access to the river is particularly difficult in towns located up-stream such as Pyzdry (JANUCHTA-SZOSTAK \& KARAŚKIEWICZ 2017). The proportion of the length of boulevards to the length of the river is presented in Table 1.

In most sections of the river in settlements, despite river engineering and embankments, the Warta is halfnatural, with significant landscape assets but poor accessibility due to those embankments. The analysis confirmed the very modest development of URAs. It is worth stressing, however, that all sections of the boulevards and promenades have been built in the last eight years, which clearly points to a growing interest in riverside areas and gradually increasing recreational activity there. Apart from the naturalness of landscape and the richness of nature, another asset is the location of historical marketplaces close to the river ${ }^{14}$. This synergic link creates an opportunity to stimulate riverside areas touristically and promote the settlement's image. This advantage, however, is insufficiently used in the towns of Wielkopolska due to the low visual quality of the waterfronts (research in progress) and a lack of riverside boulevards (e.g. in Oborniki or Międzychód). A good example of improved accessibility

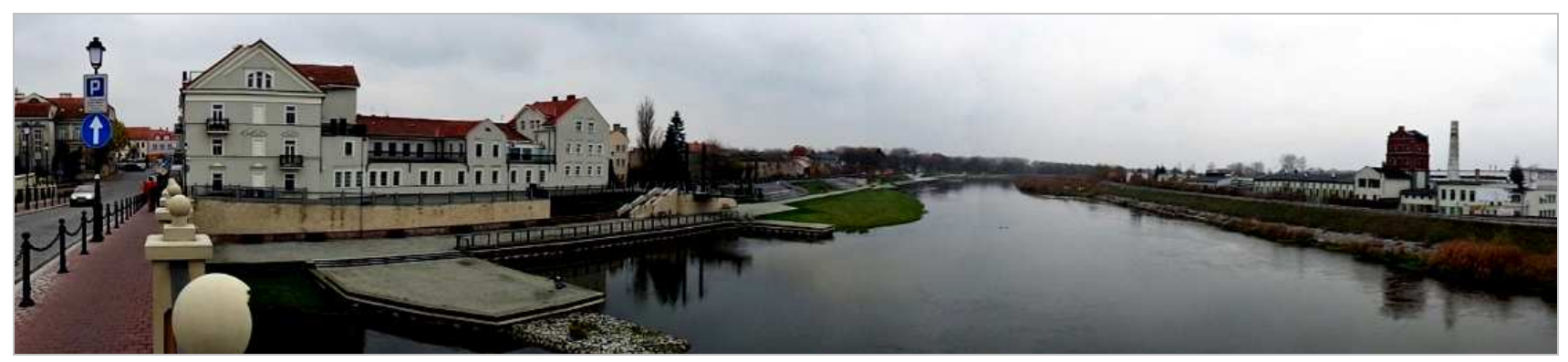

Photo 1. Warta Boulevard in Konin Source: A. Januchta-Szostak

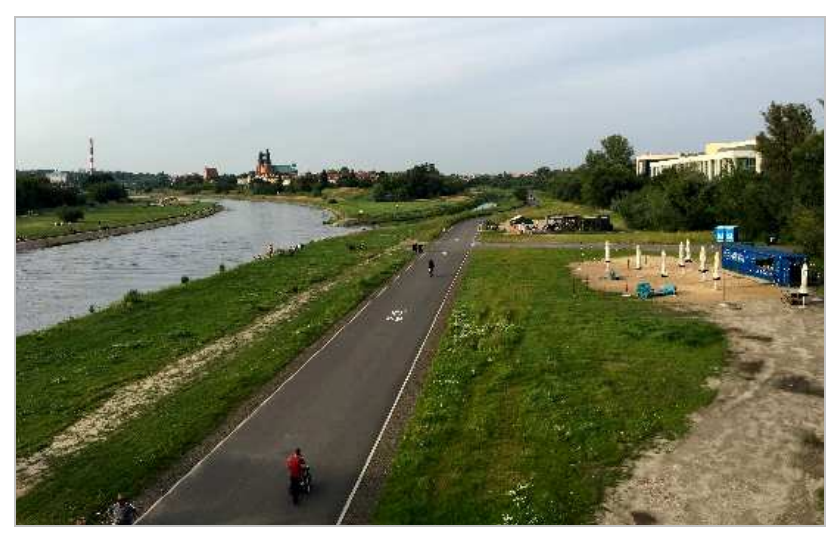

Photo 2. Warta Boulevard in Sieraków adjoining the harbour

Source: W. Henicz

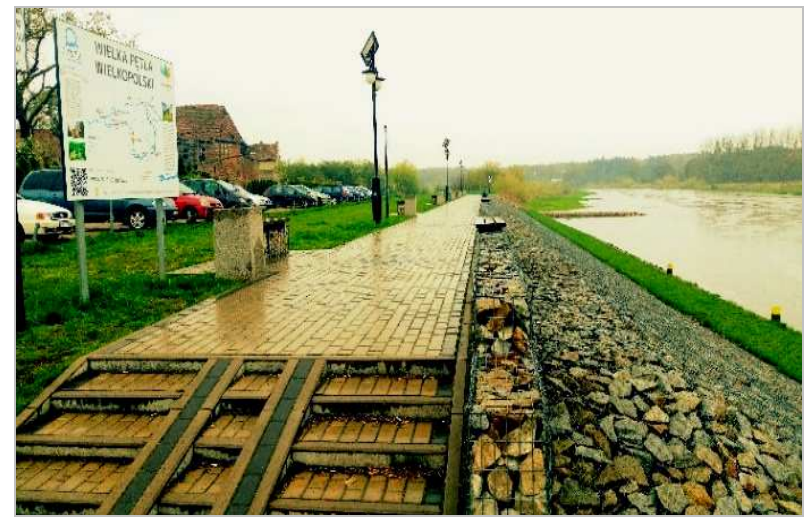

Photo 3. Wartostrada - a cycle track in Poznań with a seasonal gastronomic infrastructure: the view from Roch Bridge Source: A. Karaśkiewicz (Florkowska)

Table 1. The length of boulevards in settlements on the Warta in Wielkopolska, in proportion to river length within administrative boundaries

\begin{tabular}{|l|c|c|c|c|}
\hline \multicolumn{1}{|c|}{ Town } & $\begin{array}{c}\text { Length } \\
\text { of boulevards } \\
(\mathrm{km})\end{array}$ & $\begin{array}{c}\text { Length of the river } \\
\text { within administrative } \\
\text { boundaries }(\mathrm{km})\end{array}$ & $\begin{array}{c}\text { Percentage of the length of } \\
\text { boulevards to the river within } \\
\text { administrative boundaries }\end{array}$ & Year of opening \\
\hline Konin & 1.0 & 12.5 & 9 & 2011 \\
\hline Śrem & 2.0 & 4.0 & 50 & 2009 \\
\hline Poznań & 5.0 & 21.5 & 23 & 2017 (unofficial opening) \\
\hline Sieraków & 0.2 & 7.0 & 3 & 2014 \\
\hline
\end{tabular}

Source: A. Karaśkiewicz (Florkowska). 
and the connection of the riverside to the settlement, is the boulevard in Konin, situated next to Plac Wolności and the orthogonal arrangement of its development. The main streets, perpendicular to the river, are bordered with observation decks.

An analysis of the accessibility and development continuity was undertaken only in urban areas, but aspects in URAs such as 'passability' and continuity of riverside and water trails, as well as tourism infrastructure in the whole region of Wielkopolska ${ }^{15}$ and along the waterway of the River Warta are significant from a tourism perspective.

\subsection{THE QUANTITATIVE AND QUALITATIVE STATE OF THE TOURISM-RECREATIONAL INFRASTRUCTURE (POINT ELEMENTS)}

\section{Harbours and marinas}

The accessibility of settlements lying on the River Warta from the waterway is determined by the location of harbours, marinas, embankments and mooring decks. An inventory and analysis of these elements ${ }^{16}$ was carried out by doing desk research on sources (includeing the internet) ${ }^{17}$ and field studies. An evaluation of the development and furnishing of marinas and harbours was made based on a set of preferred elements ${ }^{18}$. Next, a harbour development coefficient ${ }^{19}$ was calculated, based on the elements available at a given place (Table 2, Fig. 5). The location and number of harbours in relation to the length of the Warta is presented in Fig. 6.

All the studied settlements in Wielkopolska have harbours which make it possible to reach the town from the river, though the level of their development and facilities, expressed with a 'development reference indicator', varies considerably. Reasonably well-developed harbours can be found in Konin, Pyzdry, Śrem, Poznań, Obrzycko (Zielonagóra) and Międzychód. In Oborniki, only three out of five existing harbours are open, but their standard is low. All open harbours feature basic facilities to moor vessels, but not all of them have toilets or gastronomic outlets. In most of them, there are benches and a place for bonfires, but there are no first aid posts.

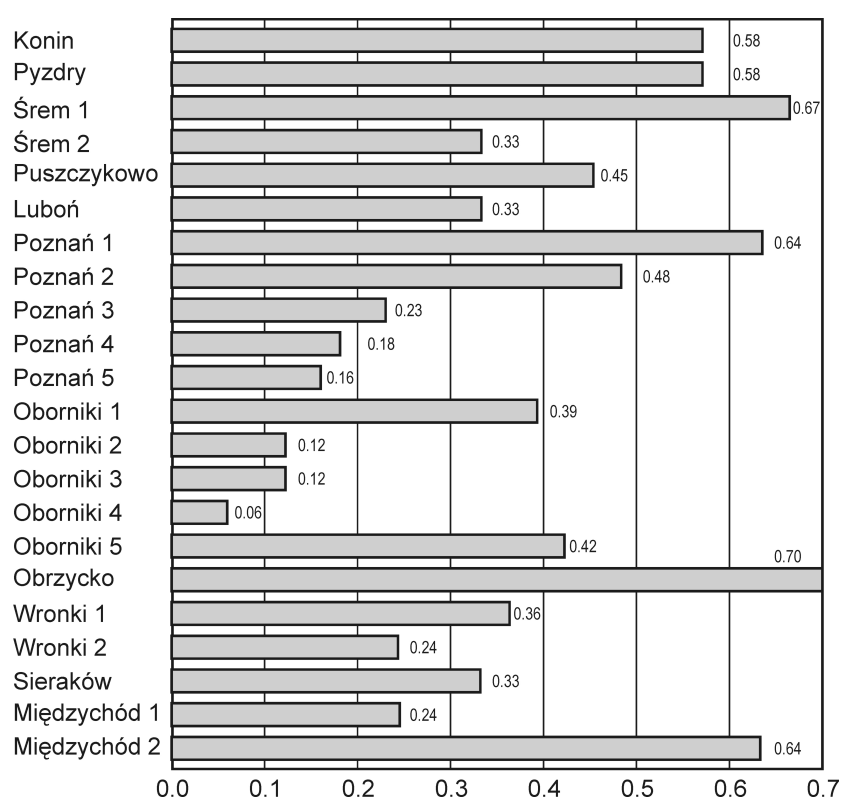

Fig. 5. The development coefficient of harbours and marinas in settlements on the Warta River in Wielkopolska

Source: A. Karaśkiewicz (Florkowska)

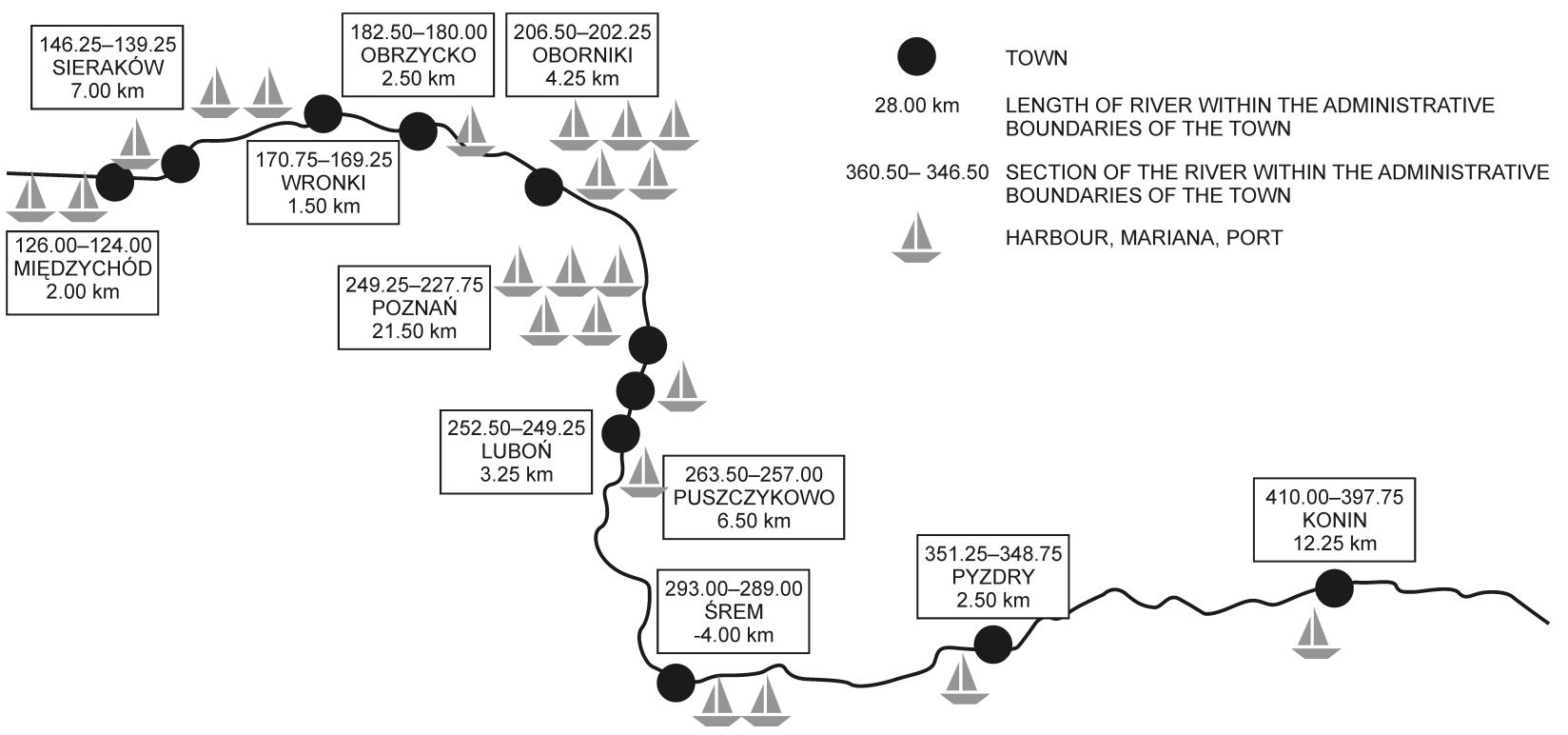

Fig. 6. Location of harbours and marinas in Wielkopolska Source: A. Karaśkiewicz (Florkowska) 
Table 2. Marinas and river harbours in Wielkopolska, their location in relation to the length of the river and the calculated development coefficient

\begin{tabular}{|c|c|c|c|c|}
\hline Town & Harbour & $\begin{array}{l}\text { Reference to chart } \\
\text { Fig. } 8\end{array}$ & $\begin{array}{l}\text { Location vs. } \\
\text { length of river } \\
(\mathrm{km})\end{array}$ & $\begin{array}{l}\text { Development } \\
\text { coefficient }\end{array}$ \\
\hline Konin & Boulevard Harbour & Konin & $403.5-404.5^{1}$ & 0.58 \\
\hline Pyzdry & Pyzdry Harbour & Pyzdry & 352.0 & 0.58 \\
\hline \multirow{2}{*}{ Śrem } & Town Harbour & Śrem 1 & 291.1 & 0.67 \\
\hline & Passenger Harbour & Śrem 2 & 291.8 & 0.33 \\
\hline Puszczykowo & Puszczykowo - Niwka harbour & Puszczykowo & 262.3 & 0.64 \\
\hline Luboń & Wioślarska Harbour & Luboń & 251.9 & 0.33 \\
\hline \multirow{5}{*}{ Poznań } & Posnania Harbour & Poznań 1 & 245.3 & 0.64 \\
\hline & KS Warta Kayak Harbour & Poznań 2 & 243.6 & 0.48 \\
\hline & Szeląg & Poznań 3 & 240.0 & 0.23 \\
\hline & Old Port & Poznań 4 & 242.1 & 0.18 \\
\hline & Kontener Art & Poznań 5 & 243.1 & 0.16 \\
\hline \multirow{5}{*}{ Oborniki } & Kowale Harbour & Oborniki 1 & 205.7 & 0.39 \\
\hline & Harbour pier at Zamkowa pizzeria & Oborniki 2 & 205.8 & 0.12 \\
\hline & Wodna Street Harbour - closed & Oborniki 3 & 205.0 & 0.12 \\
\hline & Old Port - closed & Oborniki 4 & 207.5 & 0.06 \\
\hline & Obornicka Marina & Oborniki 5 & 206.0 & 0.42 \\
\hline Obrzycko & $\begin{array}{l}\text { Kayak Harbour with sport and recreation } \\
\text { facilities in Zielonagóra }\end{array}$ & Obrzycko & 182.3 & 0.70 \\
\hline \multirow{2}{*}{ Wronki } & Wronki Harbour in Olszynki & Wronki 1 & 171.4 & 0.36 \\
\hline & 'Na Skarpie' Harbour & Wronki 2 & 171.0 & 0.24 \\
\hline Sieraków & Warta Harbour in Sieraków & Sieraków & 145.0 & 0.33 \\
\hline \multirow{2}{*}{ Międzychód } & Warta River Watchtower & Międzychód 1 & 127.5 & 0.24 \\
\hline & Old Port & Międzychód 2 & 128.0 & 0.64 \\
\hline
\end{tabular}

${ }^{1}$ The location in relation to one kilometre of river was defined on the basis of the flood hazard maps. In the case of Konin, the location of a part of the boulevard was defined because the inventoried elements were found along a longer section of the river. In the remaining cases, their point location was defined.

Source: A. Karaśkiewicz (Florkowska).

\section{Recreational and sports facilities}

In the eleven studied settlements, the authors used internet sources and field questionnaires to make an inventory of facilities having recreational functions including sports and cultural), located in the URA belt. The aim was to analyse the distribution and diversification of recreational facilities (buildings and 'open structures') in the riverside areas, as well as their functional connections with the river valley ${ }^{21}$.

The results of the analysis still require completion and verification, but a preliminary inventory indicates that the recreational-sports infrastructure of Wielkopolska settlements in URAs is quite modest (the largest number can be found in Poznań). Even though the inventory included a considerable number having recreational and sports functions, a great majority of them do not take advantage of the close proximity of the river. Quite often, the only ones functionally related to the river valley and water, are river harbours.

Urban beaches (Poznań, Konin, Luboń) can occasionally be found with permanent or seasonal facilities, as well as picnic areas (e.g. wooden 'arbours' on the Warta in Puszczykowo). The only thing that links some gastronomic or sports establishments (football grounds, sports halls) to the river valley is the view; they take advantage of the beauty of the riverside landscape, especially those riverside panoramas that are enriched with landscape dominants in the form of architectural elements of high cultural significance (e.g. the Franciscan Monastery Complex in Pyzdry, the Old Town and Ostrów Tumski in Poznań). Regrettably, the aesthetic value of some recreational facilities (the seasonal ones in particular, cf. Photo 2) diminishes the beauty of the Warta Valley landscape ${ }^{22}$.

\section{SUMMARY AND CONCLUSIONS}

The settlements located on the Warta River in Wielkopolska are gradually changing their riverside image, and this is connected with activating URAs and a better use of their recreational potential. Research on their 
functional-spatial structure and the state of development of eleven settlements enabled the authors to collect and analyse data regarding: riverside areas intended to have recreational functions, the accessibility and continuity in the development of embankments, particularly the occurrence of riverside boulevards and promenades as linear elements, as well as the location and facilities of marinas and harbours as point elements of the recreational infrastructure related to water tourism.

The percentage of areas intended to have recreational functions in the URA belt, calculated on the basis of planning documents, is low and ranges from 0.00 in Pyzdry, Oborniki and Obrzycko to 27\% in Sieraków, which indicates shortages of developed recreational areas in the majority of settlements, or at least to the fact that the recreational potential of the riverside areas is not taken into account in spatial planning. Investments in the URA zone are certainly limited due to the level of flood risk, but also because of ownership, legislative and economic issues, whose influence may well be the subject of a separate study.
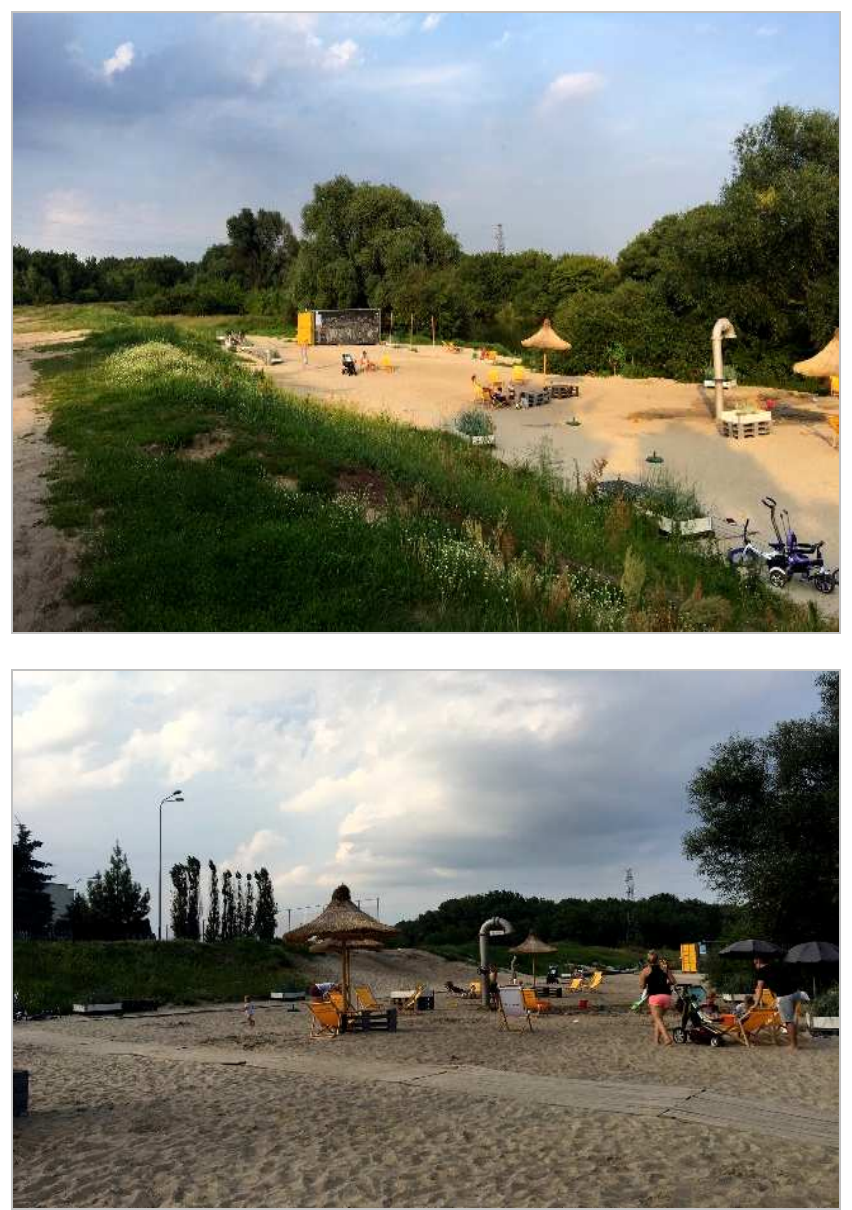

Photo 4. The town beach on the Warta River in Lubon, July 2017

Source: A. Karaśkiewicz (Florkowska)
However, in recent years, investments in the recreational infrastructure have increased due to EU funds. In Konin, Śrem, Poznań and Sieraków, sections of riverside boulevards have been built. In all settlements, there are river harbours (sometimes even two or three), which is the main factor stimulating water tourism along the Great Waterway Loop of Wielkopolska. The development level of these harbours, however, varies significantly.

In the majority of settlements, the riverside recreational infrastructure is quite modest and limited to harbours; occasionally, town beaches and picnic areas can also be found. Increased investment activity as regards riverside recreational infrastructure (especially in the form of seasonal facilities) can be observed in medium-sized towns and large cities, whose inhabitants are more and more commonly using the assets of the river.

\section{ENDNOTES}

1 Within the framework of academic project no 10/01/DSPB/ 0260, financed from funds allocated to statutory activities by the Ministry of Science and Higher Education in 2016 and 2017, at the Architecture Department, Technical University of Poznań, entitled "Pro-ecological creation of public spaces and buildings" (stage II).

2 Overlay analysis - a method used in cartography, landscape architecture and spatial planning (first used for these purposes by J. MCHARG (1969) when studying the Potomac River Valley. The development of overlay analysis led to the creation of a Geographical Information System (GIS).

${ }^{3}$ BIP - Biuletyn Informacji Publicznej (Public Information Bulletin) - a system of websites created in order to share public information online. The bulletin consists of webpages, where public authorities and other bodies performing public tasks share public information as required by Polish law. Source: https:// www.bip. gov.pl/, accessed 24.02.2018.

${ }^{4}$ In studies by M. Pietrzak, the tunnel valleys and river valleys of central Wielkopolska were considered to be areas of the highest potential (PIETRZAK 2013).

5 Tourism development also greatly depends on accommodation and gastronomic facilities, but these components were ignored in this research.

${ }^{6}$ The researchers used SUiKZP graphic attachments of the town on the Warta in Wielkopolska, as well as satellite photos and basemaps for the studied area.

7 SUiKZP - study of the conditions and directions for spatial development (Spatial planning and development Act of 27 March 2003).

8 Research conducted as part of pracownia badawcza (research laboratory) classes, entitled "Water in architecture and urban planning", conducted at the Department of Architecture, Technical University of Poznań, in 2016/2017.

9 The differentiation between sport and recreation and managed open spaces follows from the provisions of SUiKZP, but all are related to areas intended for recreation.

${ }^{10}$ Flood hazard and flood risk maps have been prepared as part of the project entitled "IT system for protection from extra- 
ordinary hazards" (ISOK) by the Institute of Meteorology and Water Economy - Centres of Flood and Draught Modelling in Gdynia, Poznań, Kraków and Wrocław. They can be accessed on http://mapy.isok.gov.pl.

11 The analysis includes areas with medium flood risk - once in 100 years $(1 \%)$.

12 For more, see: A. JANUCHTA-SZOSTAK, A. KARAŚKIEWICZ (2017).

13 By 'informal riverside paths' the authors mean dirt paths, 'shortcut footpaths', created as a result of using recreational space, not marked on maps.

${ }^{14} \mathrm{It}$ is usually a distance of ca. $200 \mathrm{~m}$. Only in Puszczykowo and Luboń, is it about $3 \mathrm{~km}$. In most towns, the walk from the marketplace to the river takes only 5 minutes, and by bicycle - 2 minutes. For more, see: A. JANUCHTA-SZOSTAK, A. FLORKOWSKA (2016), pp. 67-83.

15 One source of data for further research on tourist development is "Dolina Warty" - studium rozwojowe dla województwa wielkopolskiego, prepared by the Provincial Spatial Planning Office, or "The strategy for tourism development in Wielkopolskie Province until 2020", for Wielkopolskie Province Marshal's Office.

16 Research conducted as part of pracownia badawcza (research laboratory) classes, entitled "Water in architecture and urban planning", conducted at the Department of Architecture, Technical University of Poznań, in 2016/2017.

17 The accessibility of embankments and the location of water infrastructure along the Warta section of the Great Waterway Loop of Wielkopolska were described in the guide "Wielka Pętla Wielkopolski" ("The Great Waterway Loop of Wielkopolska") by M. SŁOWIŃSKI \& G. NADOLNY (2007); the data is updated on http://www.wielka-petla-wielkopolski.html.

${ }^{18}$ For the purposes of the study, the referential development and furnishing infrastructure was defined, including 33 elements: bridges, floating bridges, permanent bridges, piers, quays, stanchions, dolphins, buoys, slipways, water tram stops, high strengthened wharfs, low strengthened wharfs, water connection, electricity connection, sewage pumping stations, trail marking, rubbish bins, first aid points, sports equipment rental, medical aid equipment, parking places, toilets, boulevards, gastronomic outlets, benches, tables, arbours, bonfire sites, car parks, access to water, descents to water.

19 The coefficient was calculated as a ratio of the number of inventoried elements at a given harbour to the number of elements of the reference infrastructure, defined by the authors of this article.

${ }^{20}$ The location in relation to one kilometre of river was defined on the basis of the flood hazard maps. In the case of Konin, the location of a part of the boulevard was defined because the inventoried elements were found along a longer section of the river. In the remaining cases, their point location was defined.

21 Those that required direct access to water (e.g. involved various forms of water recreation) were studied, which took advantage only of the landscape assets of the valley.

${ }^{22}$ Landscape value and study of the influence of recreational development on the visual quality of the waterfronts of Warta towns is the next stage of the research.

\section{BIBLIOGRAPHY}

BERNAT S., 2007, Rewitalizacja dolin rzecznych w miastach, [in:] U. Myga-Piątek (ed.), Doliny rzeczne. Przyroda - krajobraz - człowiek, Komisja Krajobrazu Kulturowego Polskiego Towarzystwa Geograficznego, pp. 255-264.

FLORKOWSKA A., 2017, Funkcja na obszarach szczególnego zagrożenia powodziowego w nadwarciańskich miastach Wielkopolski, [in:] J. Nyćkowiak, J. Leśny (eds.), Badania i Rozwój Młodych Naukowców w Polsce, Architektura, Wyd. Młodzi Naukowcy, Poznań, pp. 13-19.

JANUCHTA-SZOSTAK A., FLORKOWSKA A., 2016, Zagospodarowanie terenów nadrzecznych w nadwarciańskich miastach Wielkopolski, [in:] A. Januchta-Szostak, M. Banach (eds.), Zrównoważone miasto - idee i realia, 1, ser. „Człowiek - Ekologia - Architektura”, Wyd. Politechniki Poznańskiej, Poznań, pp. 67-83.

JANUCHTA-SZOSTAK A., KARAŚKIEWICZ A., 2017, Nadrzeczne bulwary jako narzędzie regeneracji miejskiej przestrzeni publicznej - studium polskich miast, [in:] A. Januchta-Szostak, M. Banach (eds.), Regeneracja miasta, 3, ser. „Człowiek - Ekologia - Architektura", Wyd. Politechniki Poznańskiej, Poznań, pp. 61-74.

KOWALCZYK A., DEREK M., 2010, Zagospodarowanie turystyczne, Wyd. Naukowe PWN, Warszawa, pp. 34-57.

MCHARG J., 1969, Design with Nature, Doubleday/Natural History Press: New York, NY.

MUSZYŃSKA-JELESZYŃSKA D., 2013, Tereny nadrzeczne w aspekcie rozwoju i rewitalizacji miast, Journal of Health Sciences, 3, 14, pp. 99-107.

PANCEWICZ A., 2004, Rzeka w krajobrazie miasta, Wyd. Politechniki Śląskiej, Gliwice

PIETRZAK M., 2013, Potencjał rekreacyjny - istota, treść i zakres pojęcia, Problemy Ekologii Krajobrazu: 'Rekreacja w krajobrazach o wysokim potencjale', XXXIV, pp. 205-211.

PRIEOBRAŻENSKIJ W.S., WIEDIENIN J.A., 1971, Geografia i oddych, Izd. Znanie, Moskwa.

PRZEWOŹNIAK M., 1991, Krajobrazowy system interakcyjny strefy nadmorskiej w Polsce, Uniwersytet Gdański, Gdańsk.

RICHLING A., 1992, Kompleksowa geografia fizyczna, PWN, Warszawa.

SŁOWIŃSKI M., NADOLNY G., 2007, Wielka Pętla Wielkopolski. Warta - Noteć - Gopto - Warta. Przewodnik nie tylko dla wodniaków, Satchwell, Warszawa.

TOŁWIŃSKI T., 1948, Urbanistyka, 1 i 2, Wyd. Ministerstwa Odbudowy, Warszawa.

Strategia rozwoju turystyki w województwie wielkopolskim do 2020 roku, 2015, Urząd Marszałkowski Województwa Wielkopolskiego, Poznań.

Ustawa z 27 marca 2003 r. o planowaniu i zagospodarowaniu przestrzennym.

Ustawa z 20 lipca 2017 r. - Prawo wodne.

http://mapy.isok.gov.pl/imap/;02.04.2017.

http:/ / www.wielka-petla.pl/wielka-petla-wielkopolski.html; 11.10.2017.

https://www.bip.gov.pl/; 24.02.2018.

Article rceived:

11 January 2018 Accepted:

23 March 2018 